Please do not remove this page

RMIT

UNIVERSITY

\title{
An exploration of the adaptive strategies of working families in the Australian construction industry
}

Lingard, Helen; Francis, Valerie

https://researchrepository.rmit.edu.au/esploro/outputs/9921863688201341/filesAndLinks?institution=61RMIT_INST\&index=null

Lingard, H., \& Francis, V. (2008). An exploration of the adaptive strategies of working families in the Australian construction industry. Engineering, Construction and Architectural Management, 15(6), 562-579. https://doi.org/10.1108/09699980810916997

Document Version: Accepted Manuscript

Published Version: https://doi.org/10.1108/09699980810916997

Repository homepage: https://researchrepository.rmit.edu.au

(c) Emerald Group Publishing Limited

Downloaded On 2023/04/26 20:45:13 +1000 
Thank you for downloading this document from the RMIT Research Repository.

The RMIT Research Repository is an open access database showcasing the research outputs of RMIT University researchers.

RMIT Research Repository: http://researchbank.rmit.edu.au/

\section{Citation:}

Lingard, $\mathrm{H}$ and Francis, $\mathrm{V} 2008$, 'An exploration of the adaptive strategies of working families in the Australian construction industry', Engineering, Construction and Architectural Management, vol. 15, no. 6, pp. 562-579.

See this record in the RMIT Research Repository at:

http://researchbank.rmit.edu.au/view/rmit:1966

Version: Accepted Manuscript

Copyright Statement: (c) Emerald Group Publishing Limited

Link to Published Version:

http://dx.doi.org/10.1108/09699980810916997 


\title{
An exploration of the adaptive strategies of working families in the Australian construction industry: perpetuating gender inequality?
}

\author{
Helen Lingard, School of Property, Construction and Project Management, RMIT \\ University
}

Valerie Francis, Faculty of Architecture, Building and Planning, The University of Melbourne

\begin{abstract}
Purpose: This paper seeks to identify the adaptive strategies of couples in which at least one spouse/partner is employed in the Australian construction industry. Approach: Most studies of work-family balance identify the determinants and outcomes of work-family conflict for individual employees. However, there is a growing recognition that analyses or work hours and coping strategies require a couple-level analysis. The reas on for this is that couples lead 'linked lives' in which the work circumstances and experiences of one spouse/partner inevitably impact upon the other spouse/partner. Quantitative and qualitative data are combined to reveal the adaptive strategies used by workers in the Australian construction industry in juggling their work and non-work lives. Results: Our results reveal that standard construction industry work practices (particularly long and atypical work hours) present significant challenges for dual earner couples. Adaptive strategies are highly gendered, most frequently involving wives or female domestic partners reducing their involvement in paid work. Practical implications: The intensification of work and demographic shifts have created a 'time squeeze' for many families who juggle two paid jobs with their family goals and responsibilities. Failure to provide regular (and reasonable) hours of employment in the construction industry is likely to perpetuate the long standing under-representation of women in the construction industry and discourage the entry of younger male employees who desire a more 'hands on' experience of parenting.
\end{abstract}

Key words: Adaptive strategies, dual earner couples, work hours, gender, domestic labour.

\section{Introduction}

Recent evidence suggests that construction industry employees are particularly at risk of work-family conflict, "a form of interrole conflict in which role pressures from the work and family domains are mutually incompatible in some respect" (Greenhaus \& Beutell, 1985, p. 77). This paper responds to a growing acknowledgment that partnered employees lead 'linked lives', in which the work 'choices' of one domestic partner are constrained by the work circumstances of the other partner. Gupta and Jenkins (1985) comment on the fact that, in dual-earner couples, in addition to the pressures posed by employees' own work roles, work-life balance may be influenced by the interaction of their own role with those of their partners. The reasoning for this is that an employee whose partner is highly involved with, and committed to, their job is likely to experience greater family pressures because their partner is likely to devote considerable time and energy to his/her own work role and will have less time to participate in family life.

Work-family conflict has been explored as the linking mechanism between workers' experiences in the work and family domains (Frone et al 1997), and consistently indicates an asymmetrical relationship, with work having as greater negative impact upon family life than family life has on work (Lingard \& Francis 2006). Longer work hours are associated with higher levels of work-to-family conflict which, in turn, is linked to 
reduced quality and increased tension in employees' family relationships. The Australian construction industry is characterised by long work hours and weekend work with a strong culture which equates time spent on the job to productivity and success.

Relationships Forum Australia (RFA) has defined 'long working hours' (i.e. those at which family relationships are negatively affected) as working 45 hours per week or more (Shepanski \& Diamond, 2007). In Australia, the average weekly hours worked by full time workers (in all industries) is 44 hours, however a study of the Australian construction industry revealed the average to be considerably greater than this, standing at 63 for site-based employees in direct construction activity, 56 for employees who work mostly in the site office and 49 for employees in the head or construction company office (Lingard \& Francis 2004).

Most analyses of work and family life balance have focused on individual level experiences. The aim of this paper is to explore the couple-level strategies used by construction industry employees and their domestic partners (wives, husbands and defacto partners) to successfully combine paid work in the construction industry with family goals and responsibilities. Quantitative and qualitative data collected from Australian construction industry employees in the public and private sector are combined to reveal the adaptive strategies used by couples.

\section{The changing workforce and the rise of the dual earner family}

Pocock (2003) describes a work-family 'collision' in Australian society in the $21^{\text {st }}$ Century, suggesting that demographic and social changes are contributing causes. The Australian Bureau of Statistics (ABS) report that women's overall participation in the paid work force in Australia has risen from 43.7\% in 1978 to 57.7\% in 2007 (ABS 2007). The proportion of all women with dependent children in the paid workforce (i.e., mothers in one-parent families and mothers in 'couple families') increased from 45.6 per cent in 1985 to 60.4 per cent in 2003 (Campbell \& Charlesworth 2005). These changes have led to the emergence of the dual earner couple as the most prevalent family form.

To further exacerbate the 'time squeeze', Australia's aging population and increasing life expectancy, mean that the number of workers with filial responsibilities is also set to increase. In 1998, persons aged 65 years or more comprised 12\% of the Australian population but are projected make up $24 \%$ of the total population by 2051 (ABS 1999). An increasing number of couples face the additional responsibility of dependent children and filial care simultaneously or sequentially - the so-called 'sandwich generation'. In Australia, women do the overwhelming majority of care for aged parents: of parents receiving primary care in 2003, 91.2 percent were cared for by their daughters. The Human Rights and Equal Opportunities Commission recently reported 'as labour force projections indicate a sustained increase in the workforce participation of women workers aged 45-64 years, and as women in this age group currently make up more than 40 percent of female primary carers, the tension between work and caring commitments is likely to become and issue for more women, and therefore for families and employers" (HREOC, 2005, p42). 
Many studies of work-family conflict have focused on the individual as a unit of analysis, identifying within-individual determinants and outcomes of work-family conflict.

Matthews, Del Priore, Acitelli \& Barnes-Farrell (2006) suggest that to study the effects of work hours and work-family conflict at an individual level is inappropriate because many of the phenomena and behaviours under consideration require two people (e.g. family relationships, helping and coping behaviours). Similarly, Jacobs and Gerson (2001) suggest that work-family balance has emerged as a critical issue not just because individuals are working longer hours but because both men and women are now working these hours. There is evidence that employees are devoting more hours to paid work than in the middle of the $20^{\text {th }}$ century (Clarkberg \& Moen, 2000). At the same time, demographic changes mean that fewer employees have a family member at home to manage the non-work aspects of their lives. The problem is therefore one of overworked couples, rather than overworked individuals. Moen and Yu (2000) describe the challenge for dual earner couples as 'the three way juggling of his job, her job and their family goals and responsibilities' (p.293).

\section{Adaptive strategies}

In planning for participation in multiple roles, interactions and negotiations within families cannot be overlooked. Couples adapt, restructure (and sometimes reduce) paid work commitments during different life stages to achieve work-family integration (Becker \& Moen, 1999; Baltes \& Heydens-Gahir 2003). Becker \& Moen (1999) suggest couples use a variety of adaptive strategies to maintain two ties to the workforce, at the same time as having enough time for family life, including the adoption of a 'one career, one job' strategy, 'placing limits' and 'trading off.' A 'one career, one job' strategy involves one partner scaling back their pursuit of career goals to devote more time to family. This is often a temporary arrangement, whereby the 'job' partner will re-engage in the pursuit of career goals once children are older. The difference between a job and a career is described by Becker and Moen (1999) as being the difference between ad hoc and flexible employment, undertaken primarily for extrinsic rewards (i.e. pay), and employment that is characterised by linear developmental progression, continuity and intrinsic rewards (e.g. satisfaction and fulfillment). 'Placing limits' involves working partners establishing reasonable limits on the amount of work hours performed and reduction in expectations for long term advancement in order to be available for family time. Workers who successfully utilize this strategy are reported to communicate the importance of family to their supervisors and co-workers and establish strict limits on their workloads (Haddock, Zimmerman, Ziemba \& Lyness 2006). Placing limits could also include refusing a promotion or opportunity that would require relocation because of the impact upon other family members. Finally, 'trading off' involves a within-couple 'trade off' as to which partner has a career and which partner 'places limits' at various stages in the life course, allowing both partners to pursue fulfilling careers at different life stages. 


\section{Research methods}

\section{Data collection}

Data were collected from a sample of employees of a public sector construction organization and a private sector contracting organization in the state of Queensland (Australia), using two complementary research methods. In the first instance, a large scale survey was conducted to collect quantitative data about hours worked and the arrangements by which work and family are managed. Details of the sampling strategy and sample characteristics are reported in Lingard \& Francis (2005)

Following the survey, a smaller sample of employees was purposefully selected to further explore the adaptive strategies adopted by construction industry employees and their families. Semi-structured interviews were conducted via the telephone. Participants in this qualitative study were selected on the basis that they had volunteered to be interviewed and provided contact details at the end of the survey data collection. Where possible, participants' domestic partners were also interviewed to explore the process by which adaptive strategies are negotiated within families. The interview schedule was based on core interview questions developed by Becker and Moen (1999) in an American study examining the work-family strategies used by dual-earner couples. Interview data were subject to thematic content analysis.

\section{Results}

\section{Survey results}

Two hundred and twenty employees of the two participating organizations completed the survey. Of these, 178 respondents $(88.1 \%)$ were male and $24(11.9 \%)$ were female. The mean age of the sample was 39.81 years $(S D=1.75)$ ranging from 22 to 67 years. The average age of male respondents was 40.98 years $(\mathrm{SD}=1.55)$, and female respondents 31.8 years $(\mathrm{SD}=7.57)$. The number of years that respondents had worked in the construction industry varied from 1 to 50, with an average of 16.59 years (SD=11.44). The average number of hours per week worked by respondents was 47.4 , with a standard deviation of 10.52 (range, 8 to 80 ). The average hours worked per week was 47.8 $(\mathrm{SD}=10.69)$ for male respondents and $44.5(\mathrm{SD}=8.856)$ for female respondents.

\section{Family structure}

Figure 1 shows a breakdown of respondents' family type by their gender. The proportion of female respondents without children $(75 \%)$ was considerably higher than the proportion of child-free, male respondents $(35 \%)$. The most frequently indicated family structure by men was 'couple with dependent children' (47\%). Only eight per cent of female employees indicated they were partnered with dependent children. 
Figure 1: Respondents' family type by gender

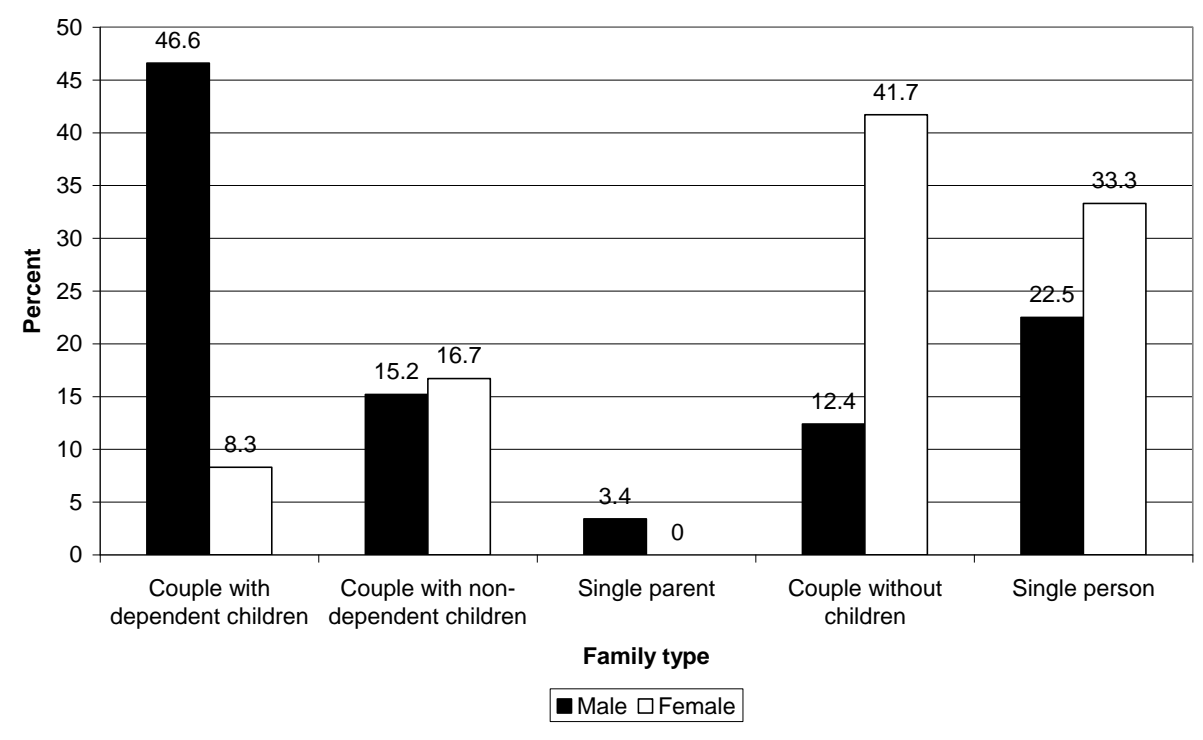

Overall, 158 of the survey respondents indicated they were partnered. Of these, 114 $(72.2 \%)$ had partners in paid employment at the time of the survey. Significant differences by sex were also observed in the employment patterns of respondents' spouses/partners. All of the female partnered respondents in the survey sample indicated that their spouse/partner was in paid employment compared to only $69 \%$ of male partnered respondents. The remaining $31 \%$ of male partnered respondents indicated a spouse/partner who was not in paid employment. 
Figure 2: Spouse/partners' hours in paid employment by gender



Figure 2 shows the average weekly hours worked by respondents' spouses/partners by their sex. The employment status (e.g. full or part time) of the spouses/partners of the female construction industry employee respondents was significantly different from those of their male counterparts. A much higher proportion of female respondents' spouses/partners worked full time, with only two female respondents indicating their spouse/partner worked part-time (i.e. less than 35 hours a week). While $45 \%$ of male construction industry employees indicated their spouses/partners work between 35 and 45 hours, only $3.1 \%$ indicated their spouse partner works 50 hours per week or more. This compares with $47 \%$ of female construction industry employees who reported their spouse partner to work between 35 and 49 hours a week and a further $41 \%$ who indicated their spouse/partner works fifty hours per week or more.

Next, participants were grouped according to the work-time commitments of themselves and their domestic partners, using an adaptation of the method developed by Moen $\& \mathrm{Yu}$ (2000). Couples were classified as follows: 'High commitments,' in which the male and female partners both work 50 or more hours each week; 'Dual moderates,' in which the male and female partner both work between 35 and 49 hours each week; 'Neo traditionalists,' in which the male partner works 50 or more hours a week and the female partner works less than 50 hours a week; 'Crossover commitments,' in which the male partner works less than 50 hours and the female partner works 50 or more hours each week; and 'Alternate commitments,' in which one partner works less than 35 hours and the other works no more than 49 hours each week. The results are presented in Table 1. 
Table 1: Partnered respondents' work-hour strategies $(\mathbf{N}=146)$.

\begin{tabular}{|l|l|l|l|l|}
\hline Work-hour strategy & His & Hers & $\%$ & $N$ \\
\hline High commitments & $50+$ & $50+$ & 2.7 & 4 \\
\hline Dual moderates & $35-49$ & $35-49$ & 21.1 & 31 \\
\hline Neo traditionalists & $50+$ & $<50$ & 40.1 & 59 \\
\hline Crossover commitments & $<50$ & $50+$ & 1.4 & 2 \\
\hline Alternate commitments & $\begin{array}{l}\text { One partner works less than } \\
\text { 35 hours, the other works no } \\
\text { more than 49 hours }\end{array}$ & 34.7 & 51 \\
\hline
\end{tabular}

The largest number of partnered respondents $(\mathrm{n}=59,40 \%)$ were classified as 'Neo traditionalists'. Thirty one respondents $(21 \%)$ were classified as 'Dual moderates.' 51 respondents $(34.7 \%)$ were classified as 'Alternate commitments.' Very few respondents $(\mathrm{n}=4,2.7 \%)$ indicated a 'High commitments' work hours strategy and only two respondents $(1.4 \%)$ were classified as 'Crossover commitments.'

In sum, these quantitative results indicate significant differences between the family structures of male and female construction industry employees in Australia, with proportionally fewer female employees having dependent children. The results also indicate that the domestic partners or spouses of male and female construction industry employees differ in their time commitments to paid work. While proportionally few female construction industry employees have a spouse/partner who works part time, 52\% of the male partnered survey respondents indicated their spouse/partner worked part time. Only $3 \%$ of the male partnered construction industry employees indicated their spouse/partner worked 50 or more hours per week compared with $41 \%$ of females. In terms of classifying couples by work commitments, the most commonly occurring form was Neo traditionalists, which is consistent with the view that husbands/partners with time-absorbing jobs are apt to have wives/partners who take up a greater share of caring and domestic work at home (Moen \& Yu, 2000).

\section{Interview results}

A total of 31 participants (24 construction industry employees and seven domestic partners) were interviewed. Twenty two construction industry participants (92\%) were male and only two (8\%) were female. Two domestic partner participants $(29 \%)$ were male and the remaining five $(71 \%)$ were female. The mean age of the interview sample was 45.6 years, ranging from 30 to 66 years.

The interviews explored the way in which couples cope with basic family functions on a day-to-day basis. Participants were asked to describe the division of domestic labour within their households. As indicated in Table 2, the majority of all interview participants $(n=24,61.3 \%)$ reported that the female partner takes on the majority of (or is solely responsible for) domestic and caring work within the household, regardless of whether she is in paid employment or not. 
Table 2: Responsibility for daily family functioning

\begin{tabular}{|c|c|c|}
\hline $\mathrm{N}=31$ & $\mathrm{~N}$ & $\begin{array}{l}\% \text { of Total } \\
\text { Sample }\end{array}$ \\
\hline $\begin{array}{l}\text { Shared 50:50 between domestic } \\
\text { partners }\end{array}$ & 12 & 38.7 \\
\hline $\begin{array}{l}\text { Female responsible for majority of } \\
\text { tasks; male responsible for some } \\
\text { regular tasks }\end{array}$ & 12 & 38.7 \\
\hline $\begin{array}{l}\text { Female solely responsible for all } \\
\text { tasks }\end{array}$ & 7 & 22.6 \\
\hline
\end{tabular}

When participants reported that domestic duties were shared equally, some division of tasks was still evident. For example, one participant commented:

".. if there's any maintenance to the house or anything like that it may be myself or any renovations required, anything of a technical nature like that. And likewise (female partner's name), being an accountant will tend towards keeping an eye on the financial side of things, paying bills and things like that. That's probably the only division; otherwise everything is split up evenly..."

When the female partner was responsible for the majority of tasks, participants frequently reported that the female partner is responsible for housework, child and other dependant care and the maintenance of family relationships, while the male partner is responsible for finances and bill paying.

Participants were asked how the division of labour was decided in their households. Table 3 shows the key themes to emerge from the responses to this question. While eight $(25.8 \%)$ participants indicated that they had actively discussed who took responsibility for daily family functioning, $16(51.6 \%)$ indicated they were unaware of how the division of family tasks had taken place, feeling it had "just happened". A further seven participants (22.6\%) reported that work commitments dictated which partner was able to take responsibility for the daily functioning of the family, a suggestion that is consistent with the notion of 'linked lives.' Participants' comments also reveal that this division of tasks was not necessarily the preferred option for the couple, sometimes creating stress and pressure in the home. 
Table 3: Organisation of daily family functioning

\begin{tabular}{|c|c|c|}
\hline Theme & $\mathbf{N}(31)$ & Descriptive Examples \\
\hline \multicolumn{3}{|l|}{ Discussed home duties: } \\
\hline $\begin{array}{l}\text { Shared } 50: 50 \\
\text { between domestic } \\
\text { partners }\end{array}$ & 6 & $\begin{array}{l}\text { ".I realised that a guy doesn't sit down and wait for } \\
\text { the food to be served to him at the table, especially } \\
\text { when there's a working wife... and we nutted that } \\
\text { out that we both have to do that sort of work...this } \\
\text { has to be done so let's help each other." } \\
\text { "Probably was some discussion...based on respect } \\
\text { and give and take." }\end{array}$ \\
\hline $\begin{array}{l}\text { Female responsible } \\
\text { for majority of tasks }\end{array}$ & 2 & $\begin{array}{l}\text { "..it is something we've talked about and came to } \\
\text { by mutual agreement." }\end{array}$ \\
\hline
\end{tabular}

Circumstances dictate duties:

\begin{tabular}{|c|c|c|}
\hline $\begin{array}{c}\text { Shared 50:50 } \\
\text { between domestic } \\
\text { partners }\end{array}$ & 1 & $\begin{array}{l}\text { "When she left work...to have our first child, we had } \\
\text { these grand plans...But a lot of the things I said I'd } \\
\text { still do I just don't do, because I don't have time to } \\
\text { do them, so she's ended up with everything." (Male } \\
\text { who cooks dinner and cares for children after work } \\
\text { and Saturdays to give female partner a break) }\end{array}$ \\
\hline $\begin{array}{c}\text { Female responsible } \\
\text { for majority of } \\
\text { tasks }\end{array}$ & 3 & $\begin{array}{l}\text { "..although I try to help wherever I can ...it's a bit } \\
\text { hard when I'm not there all the time. ..I guess it } \\
\text { happened by availability and practicality." } \\
\text { "It's a function of where I am in relation to where I } \\
\text { live. It just can't happen. There's only one option if } \\
\text { I want to work here then that's that." (Employee } \\
\text { who works 6-7 hours drive from home, commuting } \\
\text { Friday night and Sunday afternoon) }\end{array}$ \\
\hline $\begin{array}{c}\text { Female solely } \\
\text { responsible for all } \\
\text { tasks }\end{array}$ & 3 & $\begin{array}{l}\text { ".I spend most of my time at work and I have a fair } \\
\text { bit to do there and I don't really spend a lot of time } \\
\text { thinking about other things outside of that I } \\
\text { suppose" } \\
\text { "It had to be me because (name), when he walks } \\
\text { back in the door can't function, he's so exhausted...I } \\
\text { do find that it's a situation that I have to constantly } \\
\text { assess and reassess and make changes to because } \\
\text { with the three children and me if someone is sick or } \\
\text { someone has a sleepless night or something happens } \\
\text { then everything turns tojelly." }\end{array}$ \\
\hline
\end{tabular}


Table 3: Organisation of daily family functioning (continued).

\begin{tabular}{|c|c|c|}
\hline $\begin{array}{c}\text { Shared 50:50 } \\
\text { between domestic } \\
\text { partners }\end{array}$ & 5 & $\begin{array}{l}\text { "It just sort offell into place, like it just happened. It } \\
\text { wasn't really a conscious decision that I would be in } \\
\text { charge of this and you be in charge of that." } \\
\text { "I think it just worked out that way...we never } \\
\text { structured it...it comes about because prior to } \\
\text { having kids for instance we naturally helped each } \\
\text { other do these things anyway. So I think it's become } \\
\text { a little more structured with the kids now. We } \\
\text { probably, you know, while one is doing one thing, } \\
\text { the other is doing another thing." }\end{array}$ \\
\hline $\begin{array}{l}\text { Female responsible } \\
\text { for majority of tasks }\end{array}$ & 7 & $\begin{array}{l}\text { "I can't remember, but I think it was sort of the } \\
\text { traditional way of things when we got married and it } \\
\text { just sort of evolved." } \\
\text { "Just happens - I look after finances - she gets the } \\
\text { kids off to school each day and does housework. } \\
\text { "It just worked out that way." }\end{array}$ \\
\hline $\begin{array}{l}\text { Female solely } \\
\text { responsible for all } \\
\text { tasks }\end{array}$ & 4 & $\begin{array}{l}\text { "It just worked out that way with the increasing } \\
\text { number of kids and the changing lifestyle; it just } \\
\text { kind of slotted in." } \\
\text { "It's just the way it happened." } \\
\text { "Natural instinct I believe." }\end{array}$ \\
\hline
\end{tabular}

Table 4 reports the adaptive strategies that interview participants indicated that they and their spouse/domestic partner used to balance work and family goals and responsibilities. 
Table 4: Adaptive strategies by parental status

\begin{tabular}{|c|c|c|c|}
\hline $\mathbf{N}=\mathbf{3 1}$ & $\begin{array}{c}\text { No } \\
\text { Children } \\
(\mathrm{N}=2)\end{array}$ & $\begin{array}{c}\text { Non- } \\
\text { Dependent } \\
\text { Children } \\
(\mathrm{N}=4)\end{array}$ & $\begin{array}{l}\text { Dependent } \\
\text { Children } \\
(\mathrm{N}=25)\end{array}$ \\
\hline Trading Off & 1 & 2 & 11 \\
\hline $\begin{array}{l}\text { Job vs Career } \\
\text { (female with job; male with } \\
\text { career) }\end{array}$ & NA & NA & 4 \\
\hline $\begin{array}{l}\text { Job vs Career and Placing } \\
\text { Limits } \\
\text { (as above but male places some } \\
\text { limits) }\end{array}$ & NA & NA & 2 \\
\hline $\begin{array}{l}\text { Single-income family } \\
\text { (male employed; female home } \\
\text { duties) }\end{array}$ & NA & 1 & 2 \\
\hline $\begin{array}{l}\text { Single income family and } \\
\text { Placing Limits } \\
\text { (male employed but places some } \\
\text { limits; female home duties) }\end{array}$ & NA & 1 & 4 \\
\hline $\begin{array}{l}\text { Dual-career } \\
\text { (no specific strategies } \\
\text { expressed) }\end{array}$ & 1 & NA & 1 \\
\hline $\begin{array}{l}\text { Dual-career with both Placing } \\
\text { Limits }\end{array}$ & NA & NA & 1 \\
\hline
\end{tabular}

Note. Non-Dependent Children are $>24$ years. Dependent Children are $<24$ years.

'Trading off' was the most commonly used adaptive strategy. This refers to couples adopting a variety of approaches to manage work and home commitments, based on current life stage and priorities. One frequently utilised 'trading off strategy' indicated by participants was the pursuit of full-time careers by both partners before the birth of children, followed by the negotiation of one partner reducing their commitment to paid work (by either taking a 'job' rather than a career or by staying home to care for young children) while the other partner's career continued to develop. Once children leave home the 'job' partner expected to resume their career while the 'career' partner expected they would reduce their time commitments to paid work.

The scaling back strategy of 'job vs career' referred to one partner being the primary breadwinner (career) and the other partner taking a job but also being primarily responsible for home duties, and having the flexibility to reduce hours or relocate the family as necessary. Consistent with previous research, our results show that when couples adopt this strategy, the female partner is the most likely to cut back their commitments to paid work. Six participants $(19 \%)$ indicated that the female partner held a 'job' while the male pursued a 'career.' One career-focused participant, who works 60 
hours per week and whose female partner has a part-time teaching job and is mainly responsible for the daily functioning of the family commented:

"She's been working just recently an extra day a fortnight and we notice the effect of that extra day a fortnight. It's a little bit more difficult to get everything organised. She's going back to three days a week."

Some interview participants indicated that they had adopted a more 'traditional' strategy for managing work-family balance, choosing a single-income family structure. Eight participants $(26 \%)$ were single income families, in which the female partner did not work outside the home. In this structure, the male is the primary breadwinner, pursuing a career, while the female makes a full-time commitment to home duties and family responsibilities. This strategy was not expressed as part of a 'trading off' strategy, but as a specific family structure. When male respondents were asked if their partner worked, responses included "No, she's a permanent mum," "No, she's a full-time mum," and "I've never had a working wife....Basically I was the breadwinner."

In some cases, an adaptive strategy also involved one partner 'placing limits' on their time commitments to work. In our interview sample, five 'single-income' males and two participants indicating a 'job-career' adaptive strategy simultaneously attempted to place limits on their time involvement in work. This included refusing to work longer hours or weekends. However, a number of interview participants described the difficulty they experienced in trying to 'place limits' as an adaptive strategy in the construction industry context. For example, one commented:

"The trouble I found with being out on the construction side of things is that it's not always compatible with family plans and aspirations. It does involve a fair amount of travel and working unfriendly hours, quite often in unfriendly places too. The sort of construction I got into was mostly remote area construction and basically forfamily reasons I chose, about 5 years ago, I decided to get out of it and take a more office-based job."

Finally, only two $(6 \%)$ of the interview participants described both partners as being equally focused and committed to their own career development. One couple had no children, and the other couple were near retirement with older non-dependent children. One dual-career couple who reported placing limits were younger (Generation X) with children, and both worked about 45 hours each a week. To balance work and family, this couple indicated that they consciously 'place limits' on working weekends and after hours.

\section{Discussion}

\section{Gendered adaptive strategies}

Taken together the quantitative and qualitative results suggest that, despite women's entry into the world of paid work and the emergence of dual earner couples as the most prevalent family form, the culture and organization of paid work is largely unchanged. The adherence to long and rigid work hours and careers built on continued participation in full-time work leave couples left to accommodate work and family life the best way 
that they are able. The results study show that the adaptive strategies adopted by employees in the Australian construction industry and their domestic partners are highly gendered, with women doing most of the 'scaling back'.

Female construction employees in the survey sample (with male partners) were much more likely to have (male) partners in full time employment than male employees, reflecting the fact that women are much less likely to benefit from a partner who is available to undertake a large share of domestic and caring responsibilities. In contrast, the most frequently utilized adaptive strategy of survey respondents and their domestic partners was the neo traditional model, based upon traditional gendered division of domestic labour.

In the face of an impending skills shortage, the Australian construction industry needs to improve its ability to attract and retain female employees. Women remain highly underrepresented in the Australian construction industry. According to the Australian Bureau of Statistics, in July 2007, 88.8\% of employed persons in the Australian construction industry were male and $11.2 \%$ were female (ABS 2007). The construction industry's rigid adherence to a masculine culture of long work hours and weekend work is likely to impede the recruitment and retention of women, whose male partners are less likely to work reduced hours and perform an equal share of domestic work and dependant care.

The qualitative interview data reinforce the gendered nature of adaptive strategies, revealing that women take greater responsibility for domestic duties, including home management and dependent care in most of the households represented. Some writers suggest that people carefully consider the interface between work and family and plan their lives accordingly (Weitzman 1994, Barnett, Gareis, James \& Steele 2003). However, our results do not support this view instead indicating that adaptive strategies used by couples are not 'chosen' as a result of careful consideration and planning. In most cases an unequal division of domestic labour was a reaction to circumstances rather than an agreed strategy within couples. Nineteen of the 31 interview participants indicated that the within-couple division of labour had was not explicitly discussed and agreed but had either arisen in response to external circumstances, such as one partner's work schedule demands (six participants), or had been adopted without conscious thought (13 participants). This unconscious assumption of traditional gender roles was reflected by comments like 'it just worked out that way.' Our results support the contention that women's 'choices' about work and family are constrained by their husband's circumstances (Moen \& Yu 2000), as well as the structure of paid jobs and traditional sex role attitudes (Crompton \& Lyonette, 2005).

Our results also suggest that scaling back strategies are commonly employed as workfamily adaptive strategies, particularly among women. In every case in which a 'job versus career' strategy was used, the female partner held the job and the male partner held the career. Despite the deployment of adaptive strategies that enable dual earner couples to maintain their ties to the paid workforce, the practical adoption of adaptive strategies remains tied to traditional sex roles and supports the continuation of a constructed (highly gendered) division of labour. Even when couples espouse egalitarian views, women 'scale back' their involvement in paid work more frequently and to a 
greater extent than do men (Drobnic, Blossfeld \& Rohwer 1999; Milkie \& Petola 1999). Becker \& Moen (1999) comment that "despite the egalitarian gender ideology that underlies the strategy of scaling back, uneven gender outcomes often result" (p.1003).

Human capital theory describes the voluntary choices made by people in investing time and effort into different activities, for example paid work and family. The theory holds that, because home management and dependent care are time consuming activities, individuals who engage in these activities will consciously decide to pursue less timeconsuming and demanding paid work roles (Vella 1994; Blau \& Kahn 2000). Human capital theorists argue that the traditional gendered division of labour in families causes women to have shorter, more discontinuous, working lives and less labour market experience than men. Women's lower level of investment in human capital development, in turn, results in them earning lower wages and perpepuates gender inequality.

The fact that, for many, the unequal division of domestic labour within couples is not so much matter of conscious choice as an accepted normative pattern suggests that traditional attitudes about sex roles are also a determining factor in the adaptive strategies of Australian construction industry employees and their domestic partners. Although a 'neo-traditional' work hours strategy was most frequently adopted by couples in the survey sample (and 'crossover commitments' are very unusual), there is evidence that Australian couples' domestic division of labour may be changing. Fifty six per cent of the survey respondents indicated the adaptive strategies used by themselves and their partners were either 'dual moderate' or 'alternate commitments' indicating that the male partner does not work the 50 plus hours each week averaged by project-based construction industry employees (Lingard \& Francis, 2004).

In recent years, there has been a substantial shift in the expectation of fathers' involvement in parenting. A recent Australian study showed that fathers now spend more time with and are closer to their children than they were 15 years ago. However, $68 \%$ of fathers said they did not spend enough time with their children, 57\% of fathers identified work-related barriers as being the critical factor preventing them from being the kind of father they would like to be and $63 \%$ of young men said they would refuse a job or promotion that had a negative impact on their family or their partner's career (unpublished reports by Russell cited in Russell and Bowman 2000). Loughlin and Barling (2001), also comment that younger workers, both male and female, are not motivated by the same rewards as their parents' generation, placing greater value on 'nonstandard' work models that enable them to enjoy a more satisfactory work-family balance. These assertions are consistent with the findings of Moen \& Yu (2000) who report that couples adopting 'dual moderates' and 'alternate commitments' work hours strategies enjoy the highest quality of life, considerably higher than either men or women in 'neo-traditional' couples.

\section{Conclusions}

The adaptive strategies revealed in our study of construction industry employees and their spouses/domestic partners are likely to work against equal employment opportunity for women in the construction industry. Female entrants into professional and managerial 
roles within the construction industry will be disadvantaged in comparison to their male counterparts, whose own adaptive strategies are more likely to resemble the breadwinnerhomemaker division. For a significant number of participants, the division of domestic labour was a reaction to the excessive job role demands of the construction industry employed partner. In these couples, the inherent 'greediness' of the construction industry (particularly in relation to job schedule demands) was a deciding factor in unequal sharing of domestic and caring responsibilities. This presents a significant opportunity for the construction industry to re-examine the structure of work within the industry as well as re-think assumptions about what constitutes an 'ideal' worker. At present, our results show a significant 'structural lag' in which job schedule demands and expectations that employees will be increasingly available to work excessive hours and weekend work in the construction industry, have not kept pace with social and demographic changes occurring within the Australian workforce. The provision of work arrangements, for example alternative work arrangements, that support meaningful career opportunities but permit a better balance between work and family life could benefit the Australian construction industry in several important respects. First, it could help to address the current gender imbalance and increase the industry's ability to attract and retain female employees - an issue of growing importance in the face of a severe skills shortage. Second, in responding to the changed expectations of younger generations of Australian men who openly state a desire for greater involvement in parenting, it would help the construction industry to recruit and motivate male (as well as female) employees.

\section{Limitations and future research}

The research was limited in that we did not attempt to link various adaptive strategies with outcomes, such as relationship, life or job satisfaction, work-family conflict perceptions or wellbeing. Future research should empirically investigate the links between the use of different types of work-family adaptive strategies and these outcomes. The sample also consisted exclusively of participants in heterosexual relationships. The adaptive strategies of gay and lesbian couples may take a very different form and should be explored in future research. Finally, the proportion of women in the sample was very low, although women were represented in a proportion similar to the Australian construction industry as a whole. Nonetheless, further research using a larger sample of female construction industry employees is desirable to provide a more in-depth analysis of the adaptive strategies of female construction industry employees.

\section{References}

Australian Bureau of Statistics. (1999). Older Participants, Australia: A Social Report, Cat No 4109, Canberra. Australian Government Printing Service.

Australian Bureau of Statistics, (2007), Australian Labour Market Statistics, Catalogue number 6105.0, Canberra

Baltes, R., \& Heydens-Gahir, H. A., (2003), Reduction of Work-Family Conflict Through the Use of Selection, Optimization, and Compensation Behaviors, Journal of Applied Psychology, 88, 1005-1018

Barnett, R. C., Gareis, K. C., James, J. B. \& Steele, J., (2003), Planning ahead: college seniors' concerns about career-marriage conflict, Journal of Vocational Behavior, 62, 305-319.

Becker, P.E. \& Moen, P., (1999). Scaling back: Dual-earner couples'work-family strategies, Journal of Marriage and the Family, 61, 995 - 1007.

Blau, F. D. \& Kahn, L. M. (2000), Gender differences in pay, Journal of Economic Perspectives, 14, 75-99.

Campbell, I. and S. Charlesworth (2004) 'Key work and family trends in Australia'. Melbourne: Centre for Applied Research RMIT. 
Clarkberg, M. \& Moen, P., (2001), The time-squeeze: Is the increase in working time due to employer demands or employee preferences? American Behavioral Scientist, 44, 1115-1136.

Crompton, R. \& Lyonette, C., (2005), The new gender essentialism-domestic family 'choices' and their relation to attitudes, The British Journal of Sociology, 56, 601-620.

Drobnic, S., Blossfeld, H-P. \& Rohwer, G., (1999), Dynamics of women's employment patterns over the family life course: A comparis on of the Unites States and Germany, Journal of Marriage and the Family, 61, 133-146.

Frone, M.R., Yardley, J.K., \& Markel, K.S. (1997). Developing and testing an integrative model of the work-family interface, Journal of Vocational Behavior, 50, 145 - 167.

Greenhaus, J.H., \& Beutell, N.J. (1985). Sources and conflict between work and family roles. Academy of Management Review, 10, 76 - 88.

Gupta, N. and Jenkins, G. D., (1985), Dual-career couples: stress, stressors, strain and strategies. In T. A. Beehr and R. S. Bhagat (Eds), Human stress and cognition in organizations: an integrated perspective. New York, Wiley-Interscience. pp 141-175.

Haddock, S. A., Zimmerman, T. S., Lyness, K. P. \& Ziemba, S. J. (2006), Practices of Dual Earner Couples Successfully Balancing Work and Family, Journal of Family and Economic Issues, 27, 207234.

Human Rights and Equal Opportunity Commission (2005) 'Striking the Balance: Women, men, work and family'. Sydney: HREOC.

Human Rights and Equal Opportunity Commission, (2007), It's about time: women, men, work and family, Final Report, Canberra.

Jacobs, J. A. and Gerson, K., (2001), Overworked individuals or overworked families?: explaining trends in work, leisure and family time, Work and Occupations, 28, 40-63.

Lingard, H. and Francis, V., (2004) - The work-life experiences of office and site-based employees in the Australian construction industry, Construction Management and Economics, 22, 991-1002.

Lingard, H. \& Francis, V. (2005) - Does work-family conflict mediate the relationship between job schedule demands and burnout in male construction professionals and managers? Construction Management and Economics. 23: pp. 733-745.

Lingard, H. \& Francis, V., (2007), 'Negative interference' between Australian construction professionals' work and family roles: evidence of an asymmetrical relationship, Engineering, Construction and Architectural Management. 14: pp. 79-93.

Loughlin, C., and Barling, J., (2001), Young workers' work values, attitudes and behaviours, Journal of Occupational and Organisational Psychology, 74, 543-558.

Matthews, R. A., Del Priore, R. E., Acitelli, L. K. \& Barnes-Farrell, J. L., (2006), Work-to-relationship conflict: crossovereffects in dual-earner couples, Journal of Occupational Health Psychology, 11, 228-240.

Milkie, M. A. \& Peltola, P. (1999), Playing all the roles: gender and the work-family balancing act, Journal of Marriage and the Family, 61, 476-490.

Moen, P. \& Yu, Y., (2000), Effective work/life strategies: working couples, work conditions, gender and life quality, Social Problems, 47, 291-326.

Pocock, B. (2003) The work/life collision: what work is doing to Australians and what to do about it. Sydney: The Federation Press.

Relationships Forum Australia (2007), An unexpected tragedy: evidence for the connection between working hours and family breakdown in Australia, Sydney

Russell G. and Bowman L. (2000) Work and Family: Current Thinking, Research and Practice. Department of Family and Community Services. Commonwealth of Australia.

Stavrou, E. T., (2005), Flexible work bundles and organizational competitiveness: a cross -national study of the European work context, Journal of Organizational Behavior, 26, 923-947.

Strazdins, L., Clements, M. S., Korda, R. J., Broom, D. H. \& D’Souza, R. M., (2006), Unsociable work? Nonstandard work schedules, family relationships and children's wellbeing, Journal of Marriage and the Family, 68, 394-410.

Vella, F., (1994), Gender roles and human capital investment: The relationship between traditional attributes and female labour market participation, Economica, 61, 191-211. 